Editorial Office: Rectorate Building, Floor V, Jl. Prof. Dr. Sumantri Brojonegoro No. 1 Bandar Lampung, 35145, INDONESIA

Mobile: +62 813-6741-6145, Phone/Fax +62 721702767

Email: jassp@kpa.unila.ac.id, Website: https://jassp.lppm.unila.ac.id

Volume 1, Number 2, October 2021

\title{
Religious Moderation as A Solution of Interfaith Marriages in Multicultural Society
}

\author{
Imam Qolyubi', Dian Ramadhan² \\ ${ }^{1}$ Arab League's Educational, Cultural and Scientific Organization University, Cairo, Mesir \\ ${ }^{2}$ Raden Intan State Islamic University of Lampung, Lampung, Indonesia \\ Correspondence: Dian Ramadhan, Raden Intan State Islamic University of Lampung, Lampung, Indonesia. \\ Email: ramadhan.dianlpg@gmail.com, Imam Qolyubi, Arab League's Educational, Cultural and Scientific \\ Organization University, Cairo, Mesir, email: imamqolyubii@gmail.com
}

Received: June, 25, 2021 Accepted: September 17, 2021 Online Published: October 28, 2021

\begin{abstract}
:
Multicultural implies differences. If it is appropriately managed, multiculturalism can generate a positive strength for national development. Conversely, if not managed properly, pluralism and multiculturalism can be destructive factors and lead to catastrophic disasters. Based on the plurality, in the field of marriage law, there is an element of pluralism or multiculturism with the occurrence of interfaith marriages. This marriage occurred khilafiyah (differences) of opinion among the scholars. There are some of them who allow interfaith marriages with the limitation that they only allow marrying women who are Ahl al-Kitab, while other scholars strictly prohibit interfaith marriages. This research was library research using the descriptive analysis method. In this case, the author sought to describe and analyze religious moderation as a solution to interfaith marriage in a multicultural society. The result of this research is that marriage between Muslim men and women of Scripture is allowed if in their actions there is a benefit and does not cause damage or harm in accordance with the principle of "jalbu al-mashalih wa daf'u al-mafashid" (taking the good and rejecting the destructive). Meanwhile, the marriage of polytheistic Muslim men and women, that is, the women from other religions other than the divine religion is strictly prohibited. In principle, its application must be based on the values of moderation, fairness, and rationality at the value of tawassuth (middle), tawazun (balanced), i'tidal (upright), and tasamuh (tolerance).
\end{abstract}

Keywords: Al-Qur'an, Marriage, and Multiculturalism

\section{Introduction}

It is a fact that humans have various ethnicities, skin colors, religions, or nations - one of the nations that have such diversity in Indonesia. Indonesian society is a society with a very complex level of diversity which is known as a multicultural society. As has been stated, multiculturalism is defined as the diversity or difference between one culture and another, so that a multicultural society can be interpreted as a group of people who live and live permanently in a place that has its own culture and characteristics that are able to distinguish between one society and another. Each society will produce its own culture, which will become the hallmark of that community. From here, the term multiculturalism emerged.

Pluralism and multiculturalism indicate the differences. If it is managed properly, it will generate positive strength for national development. Conversely, if not managed properly, pluralism and multiculturalism can be destructive factors and lead to catastrophic disasters. Conflicts and social violence which often occur between community groups are part of pluralism and multiculturalism that is not well managed. Regardless of the pros and cons, multiculturalism is a fact that is in front of us because Indonesian society is a heterogeneous and multicultural society with various ethnicities and cultures. In such conditions, what is needed is not monoculture but multicultural, not assimilation but renewal, not co-existence but pre-existence, not an exclusive attitude but an inclusive attitude, not separation but interaction. Nor is it plurality for the sake of plurality, or plurality just 
for colors, but pluralism built on a participatory and emancipatory multicultural foundation. Some of the previous studies that also discussed themes around multiculturalism and interfaith marriage are:

First is a journal from Roswati Nurdin entitled "Multiculturalism in the Review of the Qur'an," the result of this research is that multiculturalism departs from the assumption of human dignity. Because humans have a noble position, the rights inherent in them must be respected and guarded. Defamation and violations of these human rights are oppressions against universal humanity. For this reason, there are several ways put forward by the AlQur'an to respect differences and avoid conflict in the midst of a multicultural society. This paper aims to reveal the efforts of the Al-Qur'an solution in realizing harmony in the midst of a multicultural society, so the prolonged social friction will not occur. (Nurdin, 2019)

Second is the journal from Heru Suparman entitled "Multicultural in the Perspective of the Qur'an." The results of this study are the Quranic view of multiculturalism which includes five characters, namely learning to live in differences, building three mutual aspects (mutual trust, understanding, and respect), open thinking, appreciation, and interdependence, as well as conflict resolution and nonviolent reconciliation. From some of these characteristics, it is formulated with verses from the Qur'an and interpretation as arguments that the concept of multicultural education is in line with Islamic teachings in regulating the order of human life on this earth, especially in the context of education. By understanding the concept of multiculturalism, it is hoped that each individual or group can accept and appreciate every difference, live side by side in peace and quiet even though they differ. So that a country and nation that are peaceful and prosperous can be formed. (Suparman, 2017)

The third is Rizal Mubit's research entitled "The Role of Religion in Indonesian Society Multiculturalism." The result of this research is that in modern society, multiculturalism is even more complex due to new cultures that continue to emerge as a result of unstoppable access to communication and information. Once there is a meeting between the globalization of the nation-state and identity groups, the emergence of these identity groups is getting stronger. Globalization will encourage the strengthening of political awareness in these groups and open awareness that encourages the importance of identity. Globalization provides an opportunity for identity groups to find the root of their identity. It is important to pay attention to religious understanding as one of the important pillars in building a just and prosperous society. That is, nervousness, fulfillment of one's own understanding, and considering others as heretical groups must be eradicated. Because in essence, there is no truth whatsoever to step on and negate other truths. (Mubit. 2016)

The difference between the author's research and previous research is that there has been no research on religious moderation as a solution to interfaith marriage in a multicultural society. The theory used in this research is the theory of al-'urf and maslahah mursalah. Etymologically, the meaning of the word 'urf' means "something that is considered good and accepted by common sense. (Khalil. 2009) The 'urf (tradition) are forms of muamalah (related to interests) that have been customary and being consistent in society. (Zahro, 2011) The 'urf is also called what is well known among mankind and is always followed both "utterance" and "action." (S. Abdullah. 1995)

The Ulama of "Ushuliyin give a definition:" What can be understood by human beings (a group of human beings) and they carry it out both in the form of words, deeds and prohibitions." (Anhari, 2008) The meaning of maslahah mursalah is a combination of two words into "maslahah mursalah" which means the principle of kemashlahatan (goodness), which is used to establish an Islamic law. It can also mean an act that has good or useful value. (Rusfi, 2017) According to Abdul Wahab Khallaf, maslahah mursalah is maslahah in which the syari does not prescribe law to create maslahah, nor is there any evidence to show its confession or cancellation. (Wahab Khallaf, 2002) Based on the definition above, mashlahah al mursalah is to establish the law in matters which are not mentioned at all in the Qur'an or Hadith, with consideration for the welfare or interests of human life that are united on the principle of attracting benefits and avoiding harm. (Adinugraha \& Mashudi, 2018) In this case, the author seeks to describe Religious Moderation As A Solution Of Interfaith Marriages In Multicultural Society.

Based on this plurality, in legal marriage, there is an element of pluralism or multiculturalism with the occurrence of interfaith marriages. This marriage occurred in khilafiyah (differences) of opinion among the scholars/ulama. There are some of them who allow interfaith marriages with the limitation that they only allow marrying women who are Ahl al-Kitab, while other scholar/ulama strictly prohibit interfaith marriages. 
Religious moderation is an effective way to overcome stagnation in thinking. This method is good for dealing with interfaith marriages in multicultural societies in Indonesia, namely by accepting differences of opinion, seeking and understanding sources of religious teachings comprehensively, and applying the concept of justice in dealing with interfaith marriages, not being fanatical about one opinion or thought only.

Therefore, in this case, the author will discuss religious moderation as a solution to interfaith marriage in a multicultural society.

\section{Method}

This research is library research, which aims to collect data and information contained in literature, such as books, manuscripts, journals, previous research, and documents. This research is descriptive-analytic, namely research that describes systematically, factually, and accurately a particular problem regarding the characteristics or certain factors. The primary data sources in this study were books related to multiculturalism and interfaith marriages. At the same time, secondary sources are books, literature, and supporting journals on research topics and previous research on the topic of discussion. Methods and techniques of data collection in this study are to collect literature related to the research and analyzed with the theory used. While the method used is qualitative research, namely research on research that is descriptive and tends to be analytical. And using the inductive method, which is a method that departs from specific knowledge or concrete events to draw generalizations or general things. In this case, the author seeks to describe and analyze religious moderation as a solution to interfaith marriage in a multicultural society

\section{Results}

\subsection{Multiculturalism in Indonesia}

Derived from the words multi (plural) and cultural (about culture), multiculturalism implies recognition of the reality of cultural diversity, which includes traditional diversity such as ethnic, racial, or religious diversity, as well as the diversity of life forms (subcultures) that emerge continually in every stage of the history of society's life. The term multiculturalism is generally accepted positively by Indonesian society. This, of course, has something to do with the reality of Indonesian society, which is plural. The root word of multiculturalism is culture. (Suparlan, 2014) Multiculturalism is an intellectual position that declares its allegiance to the notion of equality, justice, and togetherness to minimize the destructive conflict space. (Mahfud, 2006)

The diversity of Indonesian society can be seen from the following facts: spread over 13,667 islands (although not entirely inhabited), divided into 358 ethnic groups and 200 sub-tribes, adhering to various religions and beliefs according to statistics: $88.1 \%$ Islam, Christianity, and Catholic $7.89 \%$, Hindu $2.5 \%$, Buddhist $1 \%$, and others $1 \%$ (provided that there are also residents who adhere to a belief that is not the official government religion, but identifies themselves as adherents to the official government religion), and Historical culture is a mixture of various cultural influences, starting from the original culture of the archipelago, Hinduism, Islam, Christianity, and also modern western culture. (Irhandayaningsih, 2012)

The appearance of multiculturalism is motivated by the need for recognition of cultural diversity, which is the daily reality of many nations, including Indonesia. The birth of multiculturalism motivated by the need for recognition of cultural diversity, with the background of the need for recognition of cultural diversity, which the daily reality of many nations, including Indonesia. Therefore, from the very beginning, multiculturalism must be recognized as an ideology, as a tool or vehicle to increase respect for the equality of all humans and their humanity which is operationally manifested through its social institutions, namely culture as a guide for life of a group of everyday people. In this context, multiculturalism is a concept that legitimizes cultural diversity. We see the strength of the principle of equality and the principle of recognition in various definitions of multiculturalism.

Multiculturalism is basically a world view that can then be translated into various cultural policies that emphasize acceptance of religious, plurality, and multicultural realities that exist in people's life. It can also be understood as a worldview that is then manifested in political consciousness. Multiculturalism includes an understanding, appreciation, and assessment of one's culture, as well as a respect and curiosity about other people's ethnic cultures. Pluralism as a multicultural basis in an Islamic perspective is sunnatullah. The phenomenon of religious and cultural plurality among mankind from ancient times until today is a fact that cannot be denied. Religious and cultural plurality can also be expressed in the formulas of religious and cultural 
pluralism. Meanwhile, Al-Qur'an is a holy book that from an early age exposed this plurality based on the naked eye because it is an integrated part of the essence of Allah's creation. (Syafii Maarif, 2009)

The consequences of multiculturalism are resistance and anti against, or at least problematic with monocultureless and assimilation, which are reasonable norms of a nation-state since the 19th century. Monocultureless requires a normative cultural unity because what being its aim is homogeneity, even though the homogeneity is still at the stage of hope or discourse and has not been realized yet (pre-existing). Meanwhile, assimilation is the emergence of a desire to unite between two or more different cultures by reducing differences in order to become a new culture. The contradiction between multiculturalism and mono-cultureless is evident from basic conflict basic assumptions, one of which legitimizes differences while the others minimize differences.

In Islam, there is also the term multiculturalism, namely the existence of a holy verse from the Qur'an which

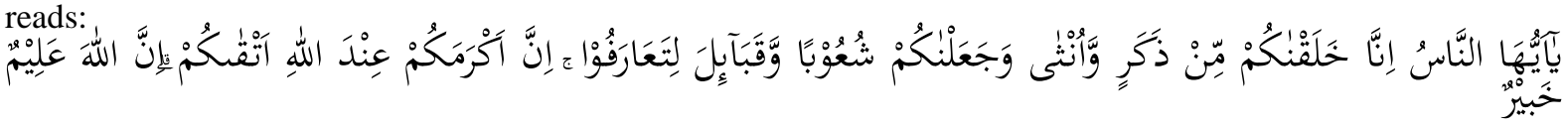

Meaning: O mankind! Lo! We have created you male and female and have made you nations and tribes that ye may know one another. Lo! the noblest of you, in the sight of Allah, is the best in conduct. Lo! Allah is Knower, Aware. (QS. Al-Hujurat [49]: 13). (Departemen Agama, 2009)

The verse above describes the diversity, beginning with the word "ya ayyuha al-nas" which means O human. In the Qur'an, besides the word syu'ub, which represents the meaning of nationality, the word qaum can also be considered to have a synonymous meaning. The words qaum and qaumiyah are often understood to mean nation and nationality. Arab nationality is declared by Arabs today by the term Al-Qaumiyah Al-Arabiyah. Likewise, with the word ummah which has the connotation of national unity and integrity. However, according to $\mathrm{M}$. Quraish Shihab, the word ummah cannot be justified as national legality because, even though the ummah is repeated 51 times, the meanings it contains are different. (Quraish Shihab, 1996)

Then they were ordered so that human beings could understand, get to know, and help each other even though there were differences in ethnicity and nationality. Allah also implies that the existence of human creation is the same as not differentiating from one another, both male and female. (Abdul Qodir, 2019) Allah also strongly reminds us of the anticipation of the possibility of an attitude and culture of mutilating and humiliating one another. Because these actions are the origin and source of social conflict. (A. Abdullah, 2000) Regarding differences and preserving culture or tradition, it is also in accordance with the rules, as follows:

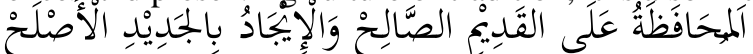

Meaning: "Preserving the good old traditions, and forming new better traditions."

This shows that a good tradition during that time is in the corridor of sharia, so it is recommended to be preserved or preserved and used in daily life. However, if the tradition or habit is not good, has no benefit, and can interfere with religious harmony, then it can be abandoned in accordance with the expression of the Prophet Muhammad's friend, Abdullah bin Mas'ud as narrated by Imam Ahmad.

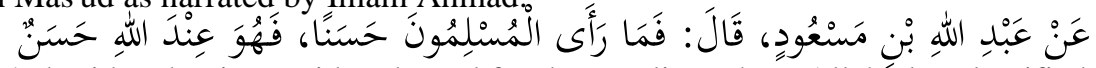

Meaning: "From Abdullah bin Mas'ud said, What is considered good for the Muslims, then Allah also classified it as a good matter."

Both from the editorial point of view and the point above, it shows that the good habits that apply in Muslim societies that are in line with the guidance of Islamic law are also good things in the sight of Allah. On the other hand, things that are contrary to habits considered good by society will give rise to difficulties and limitations in daily life. As for the rules of fiqhiyyah used in al- 'Urf, namely:

$$
\text { العادة المخكمة }
$$

Meaning: "tradition is law."

As for 'urf, there is 'urf shahih, which is a habit that is in accordance with Islamic law, then there is 'urf fasid, which is a habit that is not done or contrary to Islamic law, such as people who will hold parties or celebrations accompanied by drunkenness for more enliven the atmosphere. The use of 'urf can be made as a mukhassash of a common sentence expression. (Sarju Abdurrahman, 2015). Various cultures or traditions that exist in 
Indonesia, it makes Indonesian society plural. Thus, it is hoped that the public can understand these differences as long as it does not interfere with the rights of others and does not disturb public order.

The moderation of Islam in Arabic is called al-Wasathiyyah al-Islamiyyah. Al-Qaradawi mentions several vocabularies that are similar in meaning to those including the words Tawazun, I'tidal, Ta'adul and Istiqamah. While in English as Islamic Moderation. (Amin, 2014) The terminology of Islamic moderation is the terminology of the many terms that are often used to refer to the labels of Muslims such as modernist, progressive and reformist Islam. This moderate terminology is considered the most appropriate among the other language. Although moderates are also often described as modernist, progressive and reformist groups, none of these terms replaces the moderate word. This is based on the legitimacy of the Al-Quran and the Hadith of the Prophet that Muslims are ordered to be moderate. This is where the moderate term finds its roots in the Islamic tradition. Moreover, the terminology wasathiyyah is an identity and wasathiyyah is the primary character of Islam. (Yanti \& Witro, 2020)

In principle, ethics in Islam is based on the principles of moderation, justice, and rationality and adhere to the values of tawassuth (middle), tawazun (balanced), i'tidal (upright), and tasamuh (tolerance). The messages of religious moderation education of principles such as flexibility and openness to reform, the principle of taysîr (easiness) in the implementation of Islamic teachings, and the principle of tolerance. (Mahrus et al. 2020)

\section{Discussion}

\subsection{Religious Moderation as a Solution of Interfaith Marriages}

Before the Marriage Law, the state of marriage law in Indonesia was diverse. Each group of the population has a different marriage law from the others. (Wahyuni, 2010) This issue raises the issue of intergroup marriage law, which is about which marriage law will be applied to marriages between two people from different groups. In fact, any religion wants marriage to take place in the same religion. Therefore, marriage law in Indonesia does not allow inter-religious or interfaith marriages; if asked by any religious scholars about a good marriage, it is a marriage that has the same religion. In the Qur'an about interfaith marriage, there are several verses, such as what Allah said:

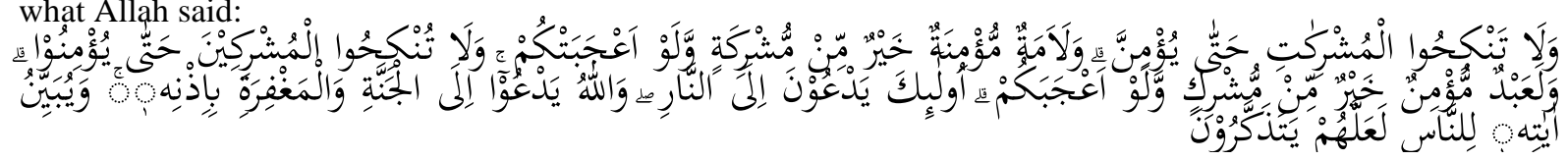

Meaning: Wed not idolatresses till they believe; for lo! a believing bondwoman is better than an idolatress though she please you; and give not your daughters in marriage to idolaters till they believe, for lo! a believing slave is better than an idolater though he please you. These invite unto the Fire and Allah invites unto the Garden, and unto forgiveness by His grace, and expounded His revelations to mankind that haply they may remember. (QS. Al-Baqarah [2]: 221)

In this verse, it is explained that believing men should not marry polytheistic women or, in other words, women who are not believers. The infidels referred to in this verse are Magi, communism, polytheism, as well as zindiq infidels who worship idols. (Yusuf Al-Subki, 2008) According to Ibn Jarir at-Thabari, the polytheists who are forbidden to marry are polytheists from the Arabs only. Because while the revelation of Qur'an, they did not know the scriptures and worshiped idols. (Santoso, 2019)

While Al-Maraghi believes that polytheism in verse is in general, polytheism. Because he uses the al-'ibrah bi 'general al-lafzhi la bi special al-sabab approach. Therefore, al-Maraghi argues that it is unlawful for a Muslim man to marry a polytheist woman. Its prohibition is not limited to Arab polytheistic women only, but it includes all polytheistic women in this world, whenever and wherever they are. (Ari Enghariano \& Amarudin, 2017) Unless they want to believe in Allah SWT and Prophet Muhammad SAW. If they believe theirs, then there is not the slightest gap for a Muslim to establish a family relationship and a marriage bond with them. (Musthafa Al-Maraghi, 1996)

Marriage in Indonesia is regulated by the Law number 1, 1974. This law consists of 14 chapters and 67 articles. For implementation, there is the Government Regulation number 9, 1975 which has been in effect since October 1st, 1975. The marriage law of 1974 is the first law that regulates marriage nationally. Previously, marriage affairs are regulated by various existing laws, ethnic law for indigenous groups, Islamic law for Muslims, Netherland Indie government ordonance for Christians in Java, Minahasa and Ambon, Book of Civil Code Kitab Undang-undang Hukum Perdata (BW) for Indonesian citizens of European and Chinese descendants, and 
mixed marriage regulation for mixed marriage. It is clear that the marriage law of 1974 was to unify and uniform various laws of marriage. (Nucholish, 2015)

Interfaith marriages between Muslims and non-Muslims are illegal because they cause of many harms; among them are interfaith marriages equal to adultery, lack of reward for worship, loss of rights to children such as alimony and guardianship, and loss of inheritance right Interfaith marriages (ikhtilafu al-din) are also explained in article 61 of KHI as one of the conditions for preventing marriage. Then it is explained that the guardians should not marry his idolatrous son until he believes. It is clear that Islam does not allow interfaith marriages. The next verse which discusses interfaith marriages is;

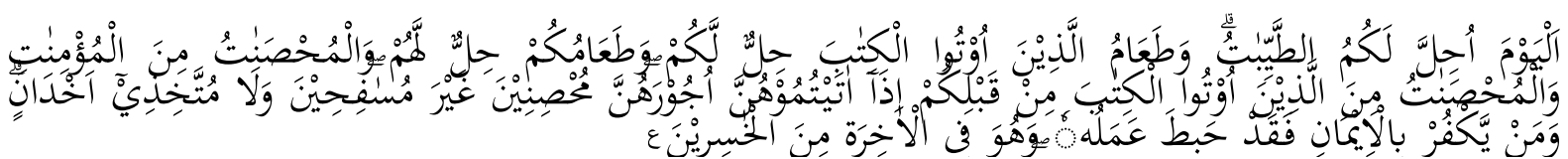

Meaning: This day is (all) good things made lawful for you. The food of those who have received the Scripture is lawful for you, and your food is lawful for them. And so are the virtuous women of the believers and the virtuous women of those who received the Scripture before you (lawful for you) when ye give them their marriage portions and live with them in honor, not in fornication, nor taking them as secret concubines. Whoso denieth the faith, his work is vain, and he will be among the losers in the Hereafter. (QS. Al-Maidah [5]: 5)

In this verse, it is explained that the women of ahlul Kitab can be married to Muslim men, according to some scholars (ulama), it is because the context of this verse is halal. Wahbah Zuhaili argues in his book Tafsir AlMunir that it is forbidden to marry between Muslims and polytheists or Muslims with infidels, whether from the group of scholars or not. This is because the polytheists, both men, and women, invite them to disbelief. (Zuhaili, 1997, p 292) In another verse, the discussion of interfaith marriages is found in verse, as follows:

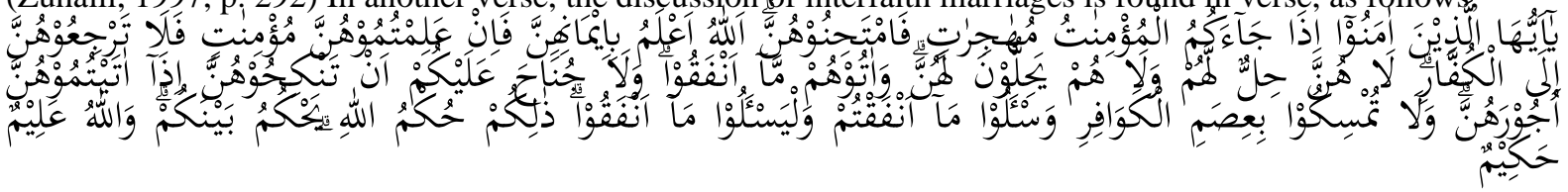

Meaning: O ye who believe! When believing women come unto you as fugitives, examine them. Allah is Best Aware of their faith. Then, if ye know them for true believers, send them not back unto the disbelievers. They are not lawful for them (the disbelievers), nor are they (the disbelievers) lawful for them. And give them (the disbelievers) that which they have spent (upon them). And it is no sin for you to marry such women when ye have given them their dues. And hold not to the ties of disbelieving women, and ask for (the return of) that which ye have spent; and let them (the disbelievers) ask for that which they have spent. That is the judgment of Allah. He judged between you. Allah is Knower, Wise. (QS. Al-Mumtahanah [60]: 10)

This verse explains that believing women are forbidden to marry or to be married by infidel men or nonMuslims. The above verses can be used as our foundation in behaving about interfaith marriage. The consideration of this provision is that the marriage will be determined by the husband who has power over his wife, and for the wives, they have to obey the good deeds. In this sense, the husband has power over the wife. However, for infidels, there is no power over Muslim men or women. (Bunyamin \& Hermanto, 2017) The sentence used in the above verses as mu'min means a person who believes in God Almighty, namely Allah SWT., and a believer is those who believe in the Prophet Muhammad SAW. Then the term infidels are people who do not believe in God and the Prophet Muhammad, and then the people of the Scripture are people who believe in the holy books revealed by God Almighty., Such as the Torah, Psalms, etc., or those who are Christians and Jews. Overall, Muslims were quite negative about these sort of marriages and more so for daughters compared to sons. This indicates that there are relatively strong religious group boundaries between Muslims and Christians in these countries. However, a substantial number of Muslims did not have negative attitudes toward these interfaith marriages, which means that there were important individuals differences in attitudes. To explain these differences, we examined religious beliefs and perceived commonality between Islam and Christianity. (Van Niekerk \& Verkuyten, 2018)

The terms used in the above verse are interrelated. Such infidels can include polytheists and the People of the Scripture, and so on. But polytheists are not the same as the People of the Scripture. The things that are agreed upon by the scholars regarding interfaith marriage; the first is there should not be a marriage between a believing or Muslim woman with an infidel man, that is, either a man from the People of the Scripture or a 
polytheist. Second, a believing man cannot marry a polytheist woman. There are different opinions among scholars about marriage between believing men and women of the People of the Scripture, namely Jews and Christians or those who believe in the scriptures, some allow, and some do not. The first opinion reveals that the People of the Scripture today are equated with the position of the polytheists because there is no greater polytheism when they do not believe in God Almighty. Allah Swt said;

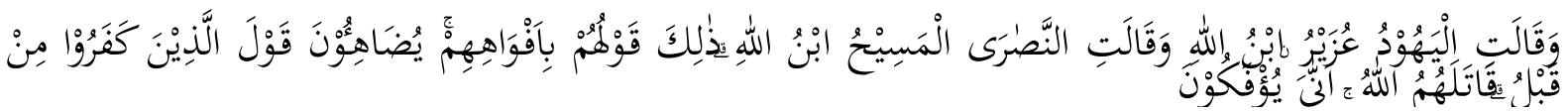

Meaning: And the Jews say: Ezra is the son of Allah, and the Christians say: The Messiah is the son of Allah. That is their saying with their mouths. They imitate the saying of those who disbelieved of old. Allah (Himself) fight against them. How perverse are they! (QS. Al-Taubah [9]: 30).

Based on this verse, some scholars argue that it cannot be tolerated when one does not believe in Allah. Some scholars disapprove of marriage between Muslims and the People of the Scripture. (Umar bin Katsir Al-Qusysi Al-Damasyqy, 1999, pp. 582-583) Because the concept in the Qur'an is clear that Muslims only believe in one God, who has no children and is not begotten as in Surah Al-Ikhlas, the second opinion reveals that allowing Muslim men to marry the People of the Scripture because of the term polytheism in the Qur'an does not include the People of the Scripture. The proof that the Qur'an distinguishes the polytheists and the People of the Scripture as in the words of Allah:

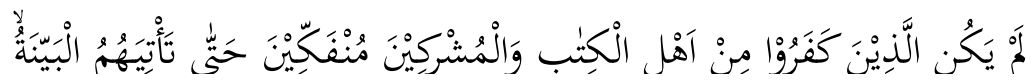
Meaning: Those who disbelieve among the People of the Scripture and the idolaters could not have left off (erring) till the clear proof came unto them. (QS. Al-Bayyinah [98]: 1)

The words of People of the Scripture and idolaters in this verse are mediated by the letter "waw." This has led some scholars to argue that there is a difference between People of the Scripture and idolaters. Then in the application of the law, it cannot be equated. Another reason is the verse that forbids the occurrence of marriage between a believer and a polytheist in surah al-Baqarah, and the ability to marry between a believing man and a woman of the People of the Scripture is found in surah al-Maidah. Because surah al-Baqarah was revealed in the early era of Madani, while al-Maidah was in the era of Madani, this is what makes some scholars argue that surah al-Baqarah cannot abolish the existing law in surah al-Maidah because of the rule that the verse that came down at the end cancels the verse that came down first. (As-Shobuni, 1999)

The wisdom of these verses is because Islam respects the heavenly religions such as Judaism and Christianity; as also discussed in the Qur'an, there is the Prophet Moses, then the Prophet Jesus. This shows that Islam gives respect to religions other than Islam, as Allah SWT says.

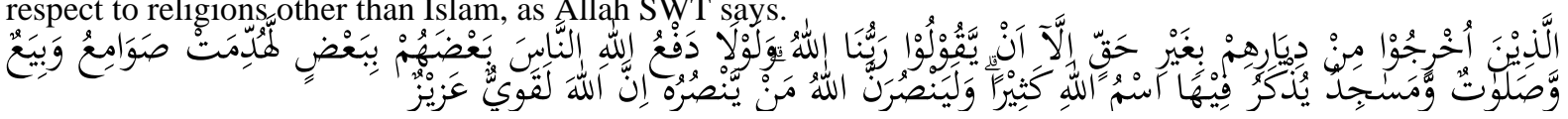

Meaning: Those who have been driven from their homes unjustly only because they said: Our Lord is Allah For had it not been for Allah's repelling some men by means of others, cloisters and churches and oratories and mosques, wherein the name of Allah is oft mentioned, would assuredly have been pulled down. Verily Allah helped one who helped Him. Lo! Allah is Strong, Almighty. (QS. Al-Hajj [22]: 40)

Ibn Asyur argues about the above verse that if there is no human defense of the places of worship of the Muslims, surely the polytheists will go beyond the limits and also aggressively against their neighboring territories whose inhabitants may profess a religion other than Islam. Religions other than Islam are also contrary to the polytheists' belief, so that monasteries, churches, and synagogues, as well as mosques, will be demolished. The polytheists' efforts simply want to eliminate monotheism's teachings and the teachings which are contrary to the ideology of polytheism. This opinion clearly positions that religions other than Islam should also receive the same respect from the Muslim community. Their places of worship, the religious symbols that they sanctify must also be honored. The verse clearly states that religious tolerance will be manifested in community life while there is a mutual respect, especially for their respective religious beliefs. (Badan Litbang Diklat, 2008)

Wisdom from allowing him to marry the People of the Scripture is to remove the obstacles to the relationship between them. With marriage, there is a mixing and family approach to each other, so that this provides an opportunity to learn about Islam. This form of relationship is one of the approaches between the Muslims and the People of the Scripture and is a doctrine of Islam towards them. Thus, Muslims who will marry a woman of 
Scripture should have that purpose and intent. (Thalib, 1993) In this case, the author argues that the ideal marriage is a marriage performed by a believer or the same religion in order to prevent the negative impact of interfaith marriages in the form of the impermanence of marital relations due to different beliefs. While the permission in Islam is if it does not cause much harm and there is a benefit, this is in line with the rule of "jalbu al-mashalih wa daf'u al-mafashid" (taking the good and rejecting the destructive). (Sholihin, 2020) While the meaning of polytheist is those who have a religion or belief other than Islam or other heavenly religions.It is permissible to marry women of Scripture because they are a heavenly religion, namely Christianity and Judaism. his is described by Sheikh Abu Zahrah that present the goodness that affects the law of marriage is fair (iqamat al- 'adl) by the husband to the wife. Meanwhile, the example of avoiding an ugliness example is zina (khawf alfahisyah). (Zahrah, 1999)

In principle, ethics in Islam is based on the principles of moderation, justice, and rationality and adhere to the values of tawassuth (middle), tawazun (balanced), i'tidal (upright), and tasamuh (tolerance). (Bagir, 2017) In this case, the application can be implemented in interfaith marriages. The value of tawassuth (middle) is by not strictly prohibiting interfaith marriages; in this case, what is allowed is Jews and Nasrani as long as the marriage does not cause much harm, but there are benefits in it. Tawazun (balanced) is the equality or balance of attitudes towards all people, that is, the existence of mutual understanding between adherents of a religion and create mutual trust. I'tidal (upright or fair) in interfaith marriages in a multicultural society is to treat everyone as they should, such as giving them a living, raising children, and so on. Then tasamuh (tolerance), this moderation value in interfaith marriages can be done when in terms of worship, which is allowing them to worship comfortably and without interference, and giving children a choice when getting adults to choose a religion that suits their conscience.

Therefore it is clear that Islam really respects the differences that exist and respects every religion, ethnicity, and race, which is summarized in multiculturalism because Islam is a religion that is rahmatan lil 'alamin, which is a blessing not only for Islam but for the whole universe.

\section{Conclusion}

This plurality also occurs in interfaith marriages. This is a matter of debate among scholars/ulama. Therefore, it is necessary to conclude using religious moderation, in this case, the author thinks that marriage between a Muslim man and a woman according to the Holy Scriptures is permissible if the act has benefits and does not cause damage or loss. Meanwhile, marriage between Muslim men and idolatrous women, namely women who have a religion other than the religion of God, is strictly prohibited. In principle, its application must be based on the values of moderation, justice, and rationality.

\section{Acknowledgments}

Our gratitude goes to the editorial staff of the Journal of Advance in Social Sciences and Policy (JASSP) and the reviewers who gave their suggestions and input for the benefit of this research. And to colleagues who have contributed to the research-making process. as well as support and assistance from all our respected parties to make this paper eligible for publication.

\section{References}

Abdul Qodir, F. (2019). Qira'ah Mubadalah. IRCiSoD.

Abdullah, A. (2000). Dinamika Islam Kultural; Pemetaan Wacana Keislaman Kontemporer. Mizan.

Abdullah, S. (1995). Sumber Hukum Islam. Sinar Grafika.

Adinugraha, H. H., \& Mashudi, M. (2018). Al-Maslahah Al-Mursalah dalam Penentuan Hukum Islam. Jurnal Ilmiah Ekonomi Islam, 4(01), 63. https://doi.org/10.29040/jiei.v4i1.140

Amin, R. (2014). PRINSIP DAN FENOMENA MODERASI ISLAM DALAM TRADISIHUKUM ISLAM. AlQalam, 20(3), 23. https://doi.org/10.31969/alq.v20i3.339

Anhari, M. (2008). Ushul Fiqh. Diantama.

Ari Enghariano, D., \& Amarudin, A. (2017). TAFSIR AYAT-AYAT HUKUM TENTANG PERNIKAHAN BEDA AGAMA Menurut Rasyid Ridha dan al-Maraghi. Jurnal Syahadah, 5(1). https://doi.org/https://doi.org/10.32520/syhd.v5i1.128

As-Shobuni, A. (1999). Tafsir Ayat Al-Ahkam min Al-Qur'an. Dar Al-Kutub Al-Ilmiyyah.

Badan Litbang Diklat, D. A. (2008). Hubungan Antar Umat Beragama (Tafsir Al-Qu'ran Tematik). Lajnah Pentashihan Mushaf Al-Qur'an.

Bagir, H. (2017). Islam Tuhan Islam Manusia (Agama dan Spiritualitas di Zaman Kacau). Mizan. 
bin Muhammad Al-Husaini Al-Damasyqy Al-Syafi'i, A. B. (1998). Kifayah Al-Akhyar fi Hilli Ghayah AlIkhtisar. Dar Al-Kutub Al-Ilmiyyah.

Bunyamin, M., \& Hermanto, A. (2017). Hukum Perkawinan Islam. Pustaka Setia.

Departemen Agama, R. I. (2009). Al-Qur'an dan Terjemahnya. PT. Sygma Examedia Arkanlema.

Irhandayaningsih, A. (2012). KAJIAN FILOSOFIS TERHADAP MULTIKULTURALISME INDONESIA. Humanika, 15(9). https://doi.org/https://doi.org/10.14710/humanika.15.9

Khalil, H. (2009). Tarikh Tasyri'. Amzah.

Mahfud, C. (2006). Pendidikan Multikultural. Pustaka Pelajar.

Mahrus, E., Prasojo, Z. H., \& Busro, B. (2020). Messages of Religious Moderation Education in Sambas Islamic Manuscripts. Madania: Jurnal Kajian Keislaman, 39. https://doi.org/10.29300/madania.v24i1.3283

Mubit, R. (2016). PERAN AGAMA DALAM MULTIKULTURALISME MASYARAKAT INDONESIA. Epistemé: Jurnal Pengembangan Ilmu Keislaman, 11(1). https://doi.org/10.21274/epis.2016.11.1.163184

Musthafa Al-Maraghi, A. (1996). Tafsir Al-Maraghi. Mathba'ah al-Halabiy.

Nucholish, A. (2015). INTERFAITH MARRIAGE IN THE CONSTITUTION AND THE ISLAMIC LAW DINAMICS IN INDONESIA. Al-Mawarid Journal of Islamic Law, 15(1), 123-142.

Nurdin, R. (2019). MULTIKULTURALISME DALAM TINJAUAN AL-QUR'AN. Jurnal Al-Asas, 3(2). https://ejournal.iainpalopo.ac.id/index.php/alasas/article/view/1634

Quraish Shihab, M. (1996). Wawasan Al-Qur'an: Tafsir Maudhui atas Pelbagai Persoalan Umat. Mizan.

Rusfi, M. (2017). Ushul Fiqh I. Seksi Penerbitan Fak. Syariah IAIN Raden Intan Bandar Lampung.

Santoso, R. (2019). ANALISIS FATWA MAJELIS ULAMA INDONESIA DAN NAHDLATUL ULAMA TENTANG PERKAWINAN BEDA AGAMA. Nurani: Jurnal Kajian Syari'ah Dan Masyarakat, 19(2), 199-208. https://doi.org/https://doi.org/https://doi.org/10.19109/nurani.v19i2.3976

Sarju Abdurrahman, W. (2015). Ijtihad Semantik dalam Ushul Fikih. Citra Pustaka.

Sholihin, B. (2020). Metode Penelitian Syari'ah. Kreasi Total Media.

Suparlan, P. (2014). Menuju Masyarakat Indonesia yang Multikultural. Antropologi Indonesia, 69. https://doi.org/10.7454/ai.v0i69.3448

Suparman, H. (2017). Multikultural dalam Perspektif Alquran. AL QUDS : Jurnal Studi Alquran Dan Hadis, 1(2), 185. https://doi.org/10.29240/alquds.v1i2.250

Syafii Maarif, A. (2009). Islam Bingkai Keindonesiaan dan Kemanusiaan: Sebuah Refleksi SejarahNo Title. Mizan.

Thalib, M. (1993). Buku Pegangan Perkawinan Menurut Islam. Al-Ikhlas.

Umar bin Katsir Al-Qusysi Al-Damasyqy, I. bin. (1999). Tafsir Al-Qur'an Al-’Adzim. Dar Al_Tayyibah li AlNastr wa Al-Tauzi'.

Van Niekerk, J., \& Verkuyten, M. (2018). Interfaith marriage attitudes in Muslim majority countries: A multilevel approach. The International Journal for the Psychology of Religion, 28(4), 257-270. https://doi.org/10.1080/10508619.2018.1517015

Wahab Khallaf, A. (2002). Ilmu Ushul Fiqh. PT. RajaGrafindo Persada.

Wahyuni, S. (2010). KONTROVERSI PERKAWINAN BEDA AGAMA DI INDONESIA. Jurnal Hukum Islam, 8(1).

Yanti, B. Z., \& Witro, D. (2020). Islamic Moderation as A Resolution of Different Conflicts of Religion. Andragogi: Jurnal Diklat Teknis Pendidikan Dan Keagamaan, 8(1), 446-457. https://doi.org/10.36052/andragogi.v8i1.127

Yusuf Al-Subki, A. (2008). Fiqh Keluarga. Amzah.

Zahrah, A. (1999). Al-Ahwal Al-Syakshiyyah. Dar Al-Fikr Al-Arabi.

Zahro, A. (2011). No Ushul Fiqh. Pustaka Firdaus.

Zuhaili, W. (1997). Tafsir Al-Munir fi Al-Aqidah wa Al-Syari'ah wa Al-Manhaj. Dar Fiqr Al-Mu'ashi. 